ISSN 2338-4778 (Print)

ISSN 2548-4192 (Online)

Volume 8, Number 2, December 2020

pp. $458-470$

\title{
Morphological Analysis of Word Formation Found in VOA News Articles
}

\author{
Annisha Dyuli Adha ${ }^{1}$, Rahma Dania ${ }^{2}$ \\ annishadyuliadha@upiyptk.ac.id \\ 1,2 FKIP, Universitas Putra Indonesia YPTK ,Padang, Indonesia
}

Received: 21 October 2020 Accepted: 22 November 2020

DOI: $10.24256 /$ ideas.v8i2.1613

\begin{abstract}
This research was aimed to analyze the types word formation and their processes which found in English articles of VOA News. This research used descriptive qualitative approach. The method in collecting the data was by searching the data in VOA News related to the articles of education, health, and science and technology. The data that contained word formation were collected and classified them based on its categories, then analyzed them based on the processes of how the words are formed. The results of this research showed that there were six types of word formation found in the VOA News articles, they were derivation, compound, acronym, initialism, clipping/ abbreviation, and conversion. From those types, compound was the most common word formation found in the articles because it was the basic division in forming the words.
\end{abstract}

Keywords: articles of VOA News; morphology; word formation

\section{Introduction}

In learning English language, the EFL students do not only learn how to construct the words becoming sentences, but they also need to learn how the words are formed, and how the words are derived from. Because of that, the students need to learn morphology to know the form of words and words varieties.

Morphology is one of linguistic branches that studies about the form of words and its morpheme. According to Lieber (2004:8), morphology is the study of word formation, including the ways new words are created in the languages. In this case, the waysof how the words are formedcan be varied depending on how they are used in the sentences by the language users. This is called as word formation process.

Wisniewski (2007) said that word formation process is pointed to the all processes which are related to the change of the word form, including its morpheme. Morpheme is also the part of morphology study. Katamba (2004: 
ISSN 2338-4778 (Print) ISSN 2548-4192 (Online)

56) stated that morpheme is the smallest unit of meaning. It means that every smallest unit found in a word, whether it is the base word or the affixes, are called as morpheme. So, the process that changes the parts of the words so that it creates the new form of the words is called by the word formation process.

According to McCarthy (2002) word formation in morphology study has many processes, such as derivation, compound, blending, acronym and initialism, inflection, borrowing, coinage, conversion, clipping, back formation, and onomatopoeia. Here are the explanation of them.

Derivation is the process of word formation by adding affixes to the word so that it changes the part of speech (the word class) as well as the meaning. For example, the word "teach (as a a verb)" if added by suffix -er, the word class can change into a noun, so that the word becomes "teacher". Because the word class changes, automatically the meaning of the word also change. While compound is the process of forming the words by joining two or more the classes of words so that it creates the new form of the word and the new meaning, for example blue eyes, big house, note book, and so on. Then, blending is the process of forming the new word by joining two or more words, but the part of the original words are omitted first before they are combined. According to Bussman (2006:786), blending is thecombination of initial letters of the first word and the final letter of the second word, for example the word "brunch" is the blend of the words "breakfast + lunch".

Next, there are also acronym and initialism. They are the types of word formation by taking the initial letters in a phrase or name. According to Barnhart (2006:670), acronymsare uttered in single words like SARS, AIDS, UNESCO, while initialism is uttered as an order of letters (letter by letter) like UK, USA, DNA. The next type of word formation is inflection. Inflection is the process of word formation by adding suffix, but it does not change the word class as well as the meaning. This is because it just indicates the grammatical function of the words (Stageberg, 2018). For example, the word "house" if added suffix $-s$ (becomes "houses"), the word class and the meaning do not change because suffix $-s$ is for indicating the plural noun.

Besides, borrowing is also the types of word formation. According to Hanif (2015:20), borrowing is the words which are borrowed from foreign language. For example, the words "risk, pizza, piano" are borrowed from Italian; "hamburger" is borrowed from Hamburg, Germany; and "limousine" is borrowed fromLimoges, France (Brinton, 2000:260).The next type is coinage. Coinage is done by using a brand name of popular product for all of the same product types. For examples, brand "Kodak" is used by the public for all of the types of camera although they have their own brand name. Then brand "Vaseline" is also used by the public to mention all of the kinds of body lotion although they have their own different name.

Then, there is also conversion as the type of word formation proccess. Conversion is the process of the changes of word class without changing the form of 
the word. For example, "butter" as a noun, and "butter" as a verb; "water" as a noun, and "water" as a verb; "empty" as a noun, "empty as an adjective, and "empty" as a verb. The next process is clipping (also called as abbreviation). It is the process of reducing one or more syllable of the word into a shorter form (Rustamaji, 2015:23). This is usually used in daily speech. For examples, the term "Prof" is a short form of "Professor"; "flu" (the short form of "influenza); "Ad" (the short form of "advertisement").

Back formation is also the type of word formation process. It is done by deleting suffix of a word so that it changes the class of the word. Examples, the word "teach(a verb)" is derived form the word "teacher(a noun)" by deleting suffix -er. So, back formation is the kind of reduction process of word formation that changes the word into the base form. The next process of word formation is onomatopoeia. It is created from the sound of things or animals then adopted into a language. For examples, "meow" is adopted from the sound of cat; "moo" (the sound of cow);"hiss" (the sound of snake).

From the processes of word formation above, the writer analyzed some of them found in VOA news articles, they are derivation, compound, initialism, acronym, clipping, and conversion.

This research has relation with some previous studies done by some researchers. First is the research done by Chudin (2008) entitled "An Analysis on Derivation of English Adjectives Found in Transhumanism of Hello Magazine". In his research, he just focused on analyzing derivational process of word formation, especially in using adjective. There were 98 data of derived adjective found in his research; they were 68 data for derived adjectives from nouns, and 30 data for derived adjectives from verbs. Comparing with Chudin's research with this research, Chudin only focused his research on derivational process of adjectives as a part of word formation and he chose Hello magazine as the object of his research. While this research focused on some types of word formation and analyzed how they are formed as the process of word formation found in VOA news articles.

Second, the research done by Hanif (2015). Hanif did a research entitled "The Analysis of Word Formation of Soccer Terms in the Jakarta Post's Articles". In his research, he got 64 data of word formation that consist of derivation, compound, initialism, reduplication, acronyms, clipping, and blending. The similarity of this research with Hanif's is they both do the same research of word formation and their processes, but they are different in the object of the research. The object of Hanif's research is Jakarta Post's articles focused on Soccer terms, while this research used VOA News articles as the object of the research related to education, science and technology, and health.

The third is the research done by Rustamaji (2015). In his research, he analyzed "The Process of English Word Formation found in Advertisement Boards in Kendal Regency". Based on the result of his research, he found 11 types of word formation, they were derivation process, cliticization, compounding, conversion, clipping, blending, backformation, acronym, onomatopoeia, inflection, and coinage. 
The similarity of this research with Rustamaji's is they both have the same topic in doing the research which analyze the word formation and their processes, but they are different in the object of the research. The object of Rustamaji's research is advertisement boards in Kendal regency, while this research used VOA News articles as the object of the research.

From the explanation, the researcher intended to do this research in order to find out the types of word formation found in VOA news articles, and analyze how the words are formed which related to the process of word formation.

\section{Method}

The approach that was used in this research was descriptive qualitative approach. According to Moleong (2010:6), qualitative research is an activity that dealed withanalyzing data by describing the object of the study. In addition, Bagdan and Taylor (through Moleong, 2002: 31) also said that the descriptive data can be produced in the written form or oral form that were got from people or observed behavior. Hence, the aspects that were described in this researchwere the results of the analysis of word formation types and their processess found in VOA news articles.

Source of data in this research was from VOA News articles which related to education, health, and science and technology. While, data of this research is word formation found in those articles.

Participants of the research were the English department students of Universitas Putra Indonesia YPTK Padang in the $4^{\text {th }}$ semester. It is because in semester 4 the students must take English morphology study. So, as the lecturer of Morphology subject, the researcher involved those students in collecting and analyzing the data from VOA News articlesto know their comprehension in learning word formation as one of indicators of English morphology subject.

In collecting the data, the researcher usedsome steps, first, searching the data in VOA news related to the articles of education, health, and science and technology. Then, collecting the data from those articles that contain word formation and classifying the data based on its types.After the data were collected and classified into their types, the researcher analyzed the types and the processess of word formation into descriptive form. These activitities were also helped by the English Department Students of Universitas Putra Indonesia YPTK Padang in semester 4 as the part of their assignments.

\section{Results}

After doing the research, finally the researcher got the findings. From the VOA news articles, it was found some types of word formation, in which the data can be seen in the following table. 
Morphological Analysis of Word Formation Found in VOA News Articles

Table 1. Word Formation found in VOA News Articles

\begin{tabular}{ccc}
\hline No & Types of Word Formation & Total of Data \\
\hline 1 & Derivation & 28 \\
2 & Compound & 53 \\
3 & Acronym & 5 \\
4 & Initialism & 11 \\
5 & Clipping/ Abbreviation & 4 \\
6 & Conversion & 18 \\
\hline Total & & 119 \\
\hline
\end{tabular}

\section{Discussion}

Here are some explanation of the table above related to the types of word formation and the processess of how they are formed.

Derivation is the process of word formation that creates new words so that it changes the word class as well as the meaning. Here are the samples of the analysis.

Table 2. Derivational Process

\begin{tabular}{cccl}
\hline No & English Words & $\begin{array}{c}\text { Types of Word } \\
\text { Formation }\end{array}$ & Process of Word Formation \\
\hline 1 & Government (n) & Derivation & Govern + suffix (-ment) \\
2 & Fearful (adj) & Derivation & Fear + suffix (-ful) \\
3 & Eventually (adv) & Derivation & Eventual + suffix (-ly) \\
4 & Movement (n) & Derivation & Move + suffix (-ment) \\
5 & Evolutionary & Derivation & Evolution + suffix (-ary) \\
& $($ adj) & & \\
\hline
\end{tabular}

In the data number 1, it can be seen that the word Government is derived from two morphemes, they are govern and suffix -ment[govern $+(-$ ment $)=$ government]. As we know that the word govern is a verb, so to make it becomes a noun, it is needed suffix -mentso that the word changes into government. In this case, suffix -ment has influence in changing the class of word, it is a verb into a noun. Because the class of word is changed, automatically the meaning of the word is also changed.

Data number 2 is also the sample of derivational process of word formation. The word fearful is derived from two morphemes, they are fear + suffix -ful[fear + $(-f u l)=$ fearful] . The word fear is a verb, so suffix -fulthat is joined with the word fear makes the class of the word is changed into adjective.

Another sample of derivational process can be seen in the data number 3 . The word eventually is derived from the word eventual which is added with suffix $-l y[$ eventual $+(-l y)=$ eventually]. As we know that the word eventual is an adjective, 
so to make it becomes an adverb, it is needed suffix -ly. Because of the change of the word class influenced by suffix -ly, it makes the meaning of the word is also changed. In this case, suffix -ly that is joined with adjective, it has function to show adverb of manner.

In the data number 4, the word movement is derived from the word move that is added with suffix (-ment), so there are two morphemes contained in that word, they are move $+(-$ ment $)=$ movement. The word move is a verb, so suffix - mentthat is joined with the word move makes the class of the word is changed into a noun.

Then, in the data number 5, the word evolutionary is derived from two morphemes, they are [evolution $+(-$ ary $)=$ evolutionary] . The wordevolution is known as a noun, so suffix -ary that is added to word evolution makes the class of the word is changed into adjective.

Compound is the process of forming the words by joining two or more the classes of words so that it creates the new form of the word and the new meaning. Besides, the head of compound words is taken place in the right part. Here are the samples of the analysis.

Table 3. Compound Process

\begin{tabular}{cccl}
\hline No & English Words & $\begin{array}{c}\text { Types of Word } \\
\text { Formation }\end{array}$ & Process of Word Formation \\
\hline 1 & Airline & Compound & air (n) + line (n) \\
2 & Distance & Compound & distance (n) + learning (n) \\
& learning & Compound & temporary (adj) + teacher \\
3 & Temporary & (n) & school (n) + work (n/ v) \\
& teacher & Compound & Note $(n)+$ book (n) \\
\hline
\end{tabular}

The data number 1 is one of the samples of compound word. The word airline is the combination of two free morphemes; air (n) and line (n). These two morphemes can stand alone and have their own meaning. However, if they are combined together, they create a new word and new meaning. This is proved by the meaning of the word that can be found in dictionary that airline is a company that offers air transportation service in the form of plane. But, it is noted that the word airline may not be written separatedly if the meaning is intended to the air transortation because it is a kind of close compound word. If the both words air and line are written separatedly, the words become air line and the meaning can be different with the airline.

Next is the compound word in the data number 2. The words distance learningare the combination of two free morphemes; distance (n) and learning (n). These two morphemes can stand alone and have their own meaning. However, if they are combined together, they create a new word and new meaning. In this case, 
the words distance learning is the kind of open compound word in which the form of the words is written separatedly. Also, the head of this compound is taken place in the right part, so the head of these words is learning not distance. Based on its meaning, distance learning is the learning process that occurs where the teacher and students do not meet face to face but occurs in a different time and place by using certain media that have been selected to achieve learning objectives.

In the data number 3 , the words temporary teacher are the combination of two free morphemes; temporary (adj) and teacher (n). These two morphemes can stand alone and have their own meaning. Although temporary is an adjective, but if it is combined together with a noun (teacher), it has function as modifier of the noun so that they create a new word, new meaning and the class of the compound word is changed into noun phrase. Also, the head of this compound is taken place in the right part, so the head of these words is learning not distance. In this case, the words temporary teacher is the kind of open compound word in which the form of the words is written separatedly. Based on its meaning, temporary teacher is a teacher that is not employed permanently and has teaching time for four weeks (minimum) or one school year (maximum).

In the data number 4, the word schoolwork isthe combination of the words school (n) and work (n/v). They both are free morpheme that can stand alone and have their own meaning. The word schoolwork is categorized into close compound word in which the form of the words is not written separatedly. In this case, the head of this compound is work not school. So, if the word school and work are combined together, they will form a new word and new meaning. Based on its meaning, schoolwork is the assignment that is given by the teacher to the students that must be done in the school or at home.

Then, in the data number 5, the word notebook is the combination of the words note (n) and book (n). They are free morpheme that can stand alone and have their own meaning. The word notebook is categorized into close compound word in which the form of the words is not written separatedly. In this case, the head of this compound is book not note. So, if the word note and book are combined together, they will form a new word and new meaning. Based on its meaning, notebook is a book that is used to note important things, especially in taking note the lesson explained by the teacher.

Acronym is the type of word formation by taking the initial letters that is uttered in a single word. 
Table 4. Initialism Process

\begin{tabular}{|c|c|c|}
\hline No & Acronym & Process of Word Formation \\
\hline 1 & COVID & Corona Virus Disease \\
\hline 2 & UNICEF & United Nations' Children Fund \\
\hline 3 & HVAC & Heating, Ventilation, and Air Conditioning \\
\hline 4 & NOAA & $\begin{array}{l}\text { National Oceanic and Atmospheric } \\
\text { Administration }\end{array}$ \\
\hline 5 & CIRES & $\begin{array}{l}\text { Cooperative InstituteforResearch in } \\
\text { Environmental Sciences. }\end{array}$ \\
\hline
\end{tabular}

In the data number 1, COVID is the acronym of Corona Virus Disease. It is called as acronym because it is uttered in the form of single word. COVID is a kind of virus that is currently phenomenal attacking public health in the world. The spread of this virus is very fast if someone cannot maintain their health properly.

In the data number 2, UNICEF is the acronym of United Nations' Children Fund. It is called as acronym because it is uttered in the form of single word.UNICEF is known as a special organization that works to help fulfill the needs of children and mothers in the developing countries.Over time, UNICEF has also focused its mission and vision to tackle violence, poverty, discrimination, epidemics and various other problems in order to create a world that respects every child's right.

The next sample of acronym is HVAC. HVAC is the acronym of Heating, Ventilation, and Air Conditioning. It is called as acronym because it is utteredinthe form of single word. HVAC is generally associated with industrial heating and cooling. HVAC is a system or machine that performs three main functions with three separate channels namely heating, cooling and air ventilation. HVAC is commonly used in industrial and commercialbuildings.

Besides, NOAA is another sample of acronym. NOAA is the acronym of National Oceanic and Atmospheric Administration. It is called as acronym because it is utteredinthe form of single word.NOAA is the America's 3rd series meteorological satellite after TIROS (Television and Indra Red Observation Satellite, 1960-1765) and IOS series (Infra Red Observation Satellite, 1970-1976).The sensor data from NOAA satellites can be used to analyze various parameters related to the fields of hydrology, oceanography, to meteorology.

In the data number 5, CIRES is the acronym of Cooperative Instituteof Research in Environmental Sciences. It is called as acronym because it is utteredinthe form of single word.In CIRes, the scientists study about the system of earth like atmosphere, geosphere, biosphere, hydrosphere, and crysophere.

Initialism is the type of word formation by taking the initial letters that is uttered letter by letter. 
Table 5. Initialism Process

\begin{tabular}{ccl}
\hline No & Initialism & \multicolumn{1}{c}{ Process of Word Formation } \\
& & \\
\hline 1 & US & United State \\
2 & WVU & West Virginia University \\
3 & ADHD & Attention Deficit Hyperactivity Disorder \\
4 & CDC & Centers for Disease Control \\
5 & FDA & Food and Drug Administration \\
\hline
\end{tabular}

In the data number 1 , US is the initialism of United State. It is called as initialism because it is uttered letter by letter. As we know that US is the initialism of United State or known as United State of America. So, most of people in the world name the country of America as US or USA.

In the data number $2, \mathrm{WVU}$ is the initialism of West Virginia University. It is called as initialism because it is uttered letter by letter. WVU is one of educational institutions (or university) in Morgantown city, USA.

The next sample is ADHD. ADHD is the initialism of Attention Deficit Hyperactivity Disorder. It is called as initialism because it is uttered letter by letter. ADHD is the mental disorders that cause a child has difficulty in focusing, as well as impulsive and hyperactive behavior, so that it can impact on children's performance in school. This condition is influenced by genetic and environmental factors. Besides, ADHD can also occur in adults.

Besides, CDCP is also the sample of initialism. CDCP is known asCenters for Disease. It is called as initialism because itis uttered letter by letter.CDC is the United States national public health agency. It functions to control and prevent infectious and chronic diseases as well as promote good health.

In the data number 5, FDA is the initialism of Food and Drug Administration. It is called as initialism because it is uttered letter by letter. FDA is the agency that oversees the distribution of drugs and food in the United States. The FDA is obliged to regulate food, dietary supplements, drugs, vaccines, pharmaceutical products, blood transfusions, medical devices, radiation therapy devices, veterinary products, and cosmetic products in the United States.

Clipping (also known as abbreviation) is the process of reducing one or more syllable of the word into a shorter form.

Table 6. Clipping/Abbreviation Process

\begin{tabular}{cccl}
\hline No & English Words & $\begin{array}{c}\text { Types of Word } \\
\text { Formation }\end{array}$ & Process of Word Formation \\
\hline 1 & Flu & $\begin{array}{c}\text { Clipping/ } \\
\text { Abbreviation }\end{array}$ & flu $\longleftarrow$ influenza \\
& &
\end{tabular}


2

4
Cigar

Ill

grandma
Clipping/

Abbreviation

Clipping/

Abbreviation

Clipping/

Abbreviation cigar $\longleftarrow$ cigarette

ill $\longleftarrow$ illness

grandma $\longleftarrow$ grandmother

In the data number 1, the word flu is the abbreviation of the word influenza. The first syllable "in-" and the final syllable "-enza" is cut to be the word flu. So, the word flu is also known as the shorten form of the word influenza.

In the data number 2, the word cigar is the abbreviation of the word cigarette. The final syllable "-ette" is cut to be the word cigar. So, the word cigar is also known as the shorten form of the word cigarette.

In the data number 3 , the word ill is the abbreviation of the word illness. The final syllable "-ness" is cut to be the word ill. So, the word ill is also known as the shorten form of the word illness.

In the data number 4, the word grandma is the abbreviation of the word grandmother. The final syllable "-ther" is cut and the letter " $o$ " is changed into " $a$ " so that the new form of the word is grandma. In daily life, many people tend to shorten the word grandmother becomes grandma.

Conversion is the process of the changes of word class without changing the form of the word.

Table 7. Conversion Process

\begin{tabular}{cccl}
\hline No & English Words & $\begin{array}{c}\text { Types of Word } \\
\text { Formation }\end{array}$ & Process of Word Formation \\
\hline 1 & Battle & Conversion & battle $(\mathrm{v}) \longleftrightarrow$ battle (n) \\
2 & Spread & Conversion & spread $(\mathrm{n}) \longleftrightarrow$ spread $(\mathrm{v})$ \\
3 & Comment & Conversion & comment $(\mathrm{n}) \longleftrightarrow$ comment $(\mathrm{v})$ \\
4 & Blow & Conversion & blow $(\mathrm{n}) \longleftrightarrow$ blow $(\mathrm{v})$ \\
5 & Ground & Conversion & ground $(\mathrm{v}) \longleftrightarrow$ ground $(\mathrm{n})$ \\
\hline
\end{tabular}

In the data number 1, the word battle which is found in VOA News article is a verb. Battle as a verb has meaning "an act or fight against group of people or something dangerous. In other side, battle is also a noun which has meaning "a fight, a struggle, a competition between people".

In the data number 2, the word spread which is found in VOA News article is a noun. Spread as a noun has meaning "the increase of something". While spread as a verb has meaning "extending the surface of something by unfolding it".

In the data number 3 , the word comment that is found in VOA News article is a noun. Comment as a noun has meaning "spoken or written statement that gives opinion on something". Whereas, comment as a verb has meaning "giving opinion 
on something".

In the data number 4, the word blow that is found in VOA News article is a noun. Blow as a noun has meaning "a hard hit with hand". While blow as a verb has meaning "sending out air from the mouth"

The next sample of conversion is also found in the data number 5 . The word ground that is found in VOA News article is a verb. Ground as a verb has meaning "preventing the planes from taking off". In contrast, ground is also a noun that has meaning "the solid surface of the earth"

From the samples of conversion above, it can be said that conversion is the kind of word formation process in which the new word is still in the same form but different in the word class.

Compared with the previous researches that have been mentioned before, this research has similarity in the focus of the research, it is about analyzing the word formation based on morphological process. However, the object and the results of this research are different with the others. In this research, the writer used VOA news as the object of the research. While the previous researches used different objects, such as Hello magazine used by Chudin (2008), Jakarta Post' articles used by Hanif 92015), and advertisement boards used by Rustamaji (2015). Besides, in this research it was found six types of word formation from the VOA news, they are derivation, compound, acronym, initialism, clipping/ abbreviation, and conversion.

\section{Conclusion}

Based on the research findings and discussion, this research is limited to the types of word formation and how the words are formed which are related to the process of word formation. Hence,there are six kinds of word formation found in VOA News articles, they are derivation, compound, acronym, initialism, clipping/ abbreviation, and conversion. In derivation process, there are 28 data found, in compound process there are 53 data. Besides, there are 5 data for acronym process, and 11 data for initialism process. For clipping/ abbreviation process, there are 4 data found, and 18 data for conversion process. From those word formation process, compound is the most common found in the VOA News articles. Those word formation processes are included into morphological analysis.

In this research, the writer that is also a lecturer of Morphology subject, involved the English Department students in the $4^{\text {th }}$ semester of Universitas Putra Indonesia YPTK Padang in collecting the data of word formation found in the VOA News articles and analyzing them based on what they have learned in Morphology subject. This was done to see their comprehension about word formation processes. Hence, this idea can be a suggestion from the writer to other researchers, especially to the lecturers to use English articles or other written media as the object of their researchby involving their students as the participants of their research in collecting and analyzing the data to increase their comprehension about word formation processes. 


\section{Acknowledgement}

The writer wants to send her deep gratitude to RISTEK-BRIN (Kementerian Riset dan Teknologi-Badan Ristek dan Inovasi Nasional) and DRPM (Direktorat Riset dan Pengabdian Masyarakat) that give contribution to the writer in funding this research in the scheme of PDP (Penelitian Dosen Pemula). Besides, the writer is also very thankful to Universitas Putra Indonesia YPTK Padang and LPPM team that always support her in doing this research. The writer also send her gratitude to other parties that help her in collecting and analyzing the data, especially to the English Department Students of Universitas Putra Indonesia YPTK Padang in the $4^{\text {th }}$ semester.

\section{References}

Barnhart, R, Steimetz, S., and Barnhart, C. (2006). Third Barnhart Dictionary of Etymology. New York: H.W. Wilson.

Brinton, Laurel, J. (2000). The Linguistic Structure of Modern English. Netherland: John Benjamins Publishing.

Bussmann, H. (2006). Routledge Dictionary of Language and Linguistics. London and New York: Routledge.

Chudin, M. (2008). An Analysis on Derivation of English Adjectives as Found in Transhumanism of Hello Magazine. Final Project of English Department FBS UNNES.

Hanif, Bahrul. (2015). The Analysis of Word Formation of Soccer Terms in the Jakarta Post's Articles. Thesis: State Islamic University Syarif Hidayatullah. Jakarta.

Herina. (2018) Analysis on the Word Formation Found in the "Jakarta Morphological Post Newspaper" Thesis S1.English and Literature Department Adab And Humanity Faculty Alauddin State Islamic University of Makassar

Maharani, S. A (2014) An Analysis of Derivational Affixes in The Land of Five Towers Novel By A. Fuadi Translated By Angie Kilbane. A Thesis S1. English Education Department Teacher Training and Education Faculty Muria Kudus University

Masruddin, M. (2018). Some Theories on Language Revitalization. IDEAS: Journal on English Language Teaching and Learning, Linguistics and Literature, 3(1). doi:https://doi.org/10.24256/ideas.v3i1.140

Mc Carthy, Andrew Carstairs. (2002). An Introduction to English Morphology: Words and Their Structures. Edinburgh: Edinburgh University Press.

Moleong. (2010). Metodologi Penelitian Kualitatif. Bandung: Remaja Rosdakarya Nurhayati, U., \& Nurkholik, N. (2018). The Morphological Processes of Bugis Language (A Morphological Study of Bugis Language through Latoa Script). IDEAS: Journal on English Language Teaching and Learning, Linguistics and Literature, 6(1). doi:https://doi.org/10.24256/ideas.v6i1.15

Rustamaji, Eko. (2015). Process of Word Formation Found in Advertisement Boards in Kendal Regency. Thesis: Semarang State University. 
Stageberg, Norman. C. (2018). An Introductory English Grammar. State College of IOWA: Holt, Rinchart and Winston, Inc.

Wagner, Martina. (2010). Word Formation Process: How New Words Develop in the English Language. Winter Term.

Wisniewski, K. (2007). Word Formation. Available at www.Humaczenia-angielski.info/linguisics/word-formation.htm [accessed Sepetember 2020).

Yule. (2010). The Study of Language. Cambridge: Cambridge University Press. 